\title{
Reforming Ratification
}

\author{
Ji Lian Yap*
}

\begin{abstract}
This paper considers recent company law reform proposals in Hong Kong in relation to the ratification of breaches of directors' duties, and also makes suggestions for further reform. In the course of this discussion, comparisons will be made with the corresponding position under the UK Companies Act 2006. Finally, several wider observations in relation to the consequences of codification of common law principles and the divergence between English and Hong Kong company law will be offered. The aim is to suggest directions for future reform in the important but somewhat inaccessible area of ratification of breaches of directors' duties. While this paper seeks to consider these issues in the light of Hong Kong, the discussion would be of interest to those from other common law jurisdictions who are examining the issue of ratification or looking with interest at the recent United Kingdom company law reform efforts and considering whether to adopt them locally.
\end{abstract}

Keywords: ratification, directors' duties, derivative action, divergence, Hong Kong

\section{Introduction}

The law relating to the ratification of breaches of directors' duties in Hong Kong is an inaccessible wilderness of case law principles and scattered statutory provisions. This paper considers the concept of ratification, with particular attention to the recent law reform efforts in Hong Kong. In the course of discussion, there will also be comparisons made with relevant provisions under the UK Companies Act 2006.

The paper starts by considering the rationale for allowing the ratification of breaches of directors' duties. It then makes suggestions as to who should be empowered to ratify breaches of directors' duties. The paper also considers what the effects of ratification should be, particularly in connection with the statutory derivative action. The thorny issue of non-ratifiable breaches will next be discussed. Several wider observations in relation to the consequences of the codification of common law principles and the divergence between English and

\footnotetext{
* Assistant Professor, Faculty of Law, University of Hong Kong; e-mail: jilyap@hkucc.hku.hk
} 
Hong Kong company law will be made. In the midst of the extensive and ongoing reforms of the company law framework in Hong Kong, the overall aim of this paper is to offer suggestions as to how coherence and clarity might be improved in this nebulous area of law. This paper seeks to consider these issues in the light of Hong Kong; however, the discussion would be of interest to those from other common law jurisdictions who are examining the issue of ratification, or are looking with interest at the recent United Kingdom company law reform efforts and considering whether to adopt them locally.

\section{The Rationale for Ratification}

Directors' duties of care and fiduciary duties exist for the protection of the company and its stakeholders, such as its shareholders and creditors. What then is the basis for allowing the ratification of breaches of these directors' duties? There appear to be at least two reasons for allowing ratification of breaches of directors' duties. First, it has been reasoned that, just as those to whom fiduciary duties are owed may release the fiduciary from his obligation, similarly the company should be able to release a director from his duty. ${ }^{1}$ This is based essentially on the idea of freedom of choice, that one can choose not only whom to sue but also whom to forgive, even if this is disadvantageous to oneself. In addition, from a pragmatic perspective, the possibility of ratification may be seen generally to encourage entrepreneurship, since there should be a means by which directors are allowed to pursue entrepreneurial interests as long as the company signifies its permission for this via ratification.

However, a key concern in exploring the concept of ratification is that other stakeholders should not be unduly prejudiced at the hands of the person(s) who have the power to ratify breaches of directors' duties. For instance, the traditional common law position is generally that ratification is effected by resolution of the company in general meeting. ${ }^{2}$ The concern then is that other stakeholders such as minority shareholders and creditors should not be prejudiced by the untrammelled exercise of the power of ratification by the majority shareholders. There is thus an inevitable balancing exercise that takes place in considering the sometimes conflicting interests of the various stakeholders of the company, to ensure that each are fairly treated.

1 P. Davies, Gower \& Davies' Principles of Modern Company Law, 8th edn (Sweet \& Maxwell: London, 2008) 581. Note, however, that the soundness of applying the trust law concept of release in the corporate context has been questioned in P. Koh, 'Directors' Fiduciary Duties: Unthreading the Joints of Shareholder Ratification' (2005) 5 Journal of Corporate Law Studies 363.

2 Regal (Hastings) Ltd v Gulliver [1967] 2 AC 134. 
However, as will be argued below, there are other more direct ways of protecting the interests of some of these stakeholders, rather than attempting the tricky exercise of balancing all their diverse interests within the law of ratification.

With this conceptual framework in mind, we can now turn to consider two related questions, namely, who should be empowered to ratify breaches of directors' duties, and what should be the effect of ratification (particularly in connection with the statutory derivative action).

In considering these questions in the Hong Kong context, only the statutory derivative action will be discussed, despite the fact that Hong Kong does currently still retain the common law derivative action within its legal framework. ${ }^{3}$ The question of whether the common law derivative action should be abolished in Hong Kong had previously been raised in law reform efforts ${ }^{4}$ in the light of judicial comments in the Hong Kong Court of Final Appeal to the effect that the common law derivative action should be replaced with the statutory derivative action altogether. ${ }^{5}$

\section{Disinterested Shareholders' Approval}

\section{i. The Requirement of Disinterested Shareholders' Approval}

The current position in Hong $\mathrm{Kong}^{6}$ is the general common law rule that ratification may be effected by the shareholders in a general meeting. ${ }^{7}$ In addition, members are entitled to vote even if they have a personal interest in the subject matter that is different from the interests of the company. ${ }^{8}$ It follows from this that generally a director who is a shareholder may vote on any question in a general meeting including the issue of ratification for a breach of his duty.

However, recent deliberations in company law reform indicate that this may be about to change in Hong Kong. It has been proposed ${ }^{9}$ that Hong Kong adopt the UK position in section 239 of the UK Companies

3 Pursuant to s. 168BC(4) of the Hong Kong Companies Ordinance (hereafter: 'Companies Ordinance').

4 Chapter 9 (Common Law Derivative Action) of the First Phase Consultation of the draft Companies Bill (17 December 2009) and the Consultation Conclusions.

5 Waddington Limited v Chan Chun Hoo Thomas [2008] HKEC 1498 para. 32, discussed in J.L. Yap, 'Whither the Common Law Derivative Action?' (2009) 38 CLWR 197.

6 The position in Hong Kong with regard to ratification is discussed in detail in P. Kwan, Hong Kong Corporate Law (Lexis Nexis, 2006) para. 26.9.2.

7 Above n. 2.

8 North West Transportation Co Ltd v Beatty (1887) LR 12 App. Cas. 589.

9 Part 10 (Directors and Secretaries) of the Explanatory Notes on the Draft Parts in the First Phase Consultation of the draft Companies Bill (17 December 2009). 
Act $2006,{ }^{10}$ which incorporated the element of disinterested shareholders' approval into the UK legislative framework for ratification. The intention in the draft Hong Kong Companies Bill is thus to preserve the current common law on ratification with an additional requirement of disinterested shareholders' approval. ${ }^{11}$

Such an amendment would go towards preventing directors who hold a majority vote from ratifying their own wrongdoing. Nonetheless, this apparently simple solution has its drawbacks. The reason for introducing the element of disinterested shareholder approval is based on the expectation that the disinterested shareholders will act in the best interests of the company. However, it has been observed that minority shareholders may not in fact necessarily act in the best interests of the company, and may instead be motivated by concern over the impact of litigation on the value of their shares. ${ }^{12}$

Given that the disinterested shareholder approval requirement may potentially give disinterested minority shareholders a disproportionate amount of power relative to their shareholding, it is uncertain as to whether it is appropriate in such circumstances to waive the wellestablished concept of majority rule. In addition, there may be circumstances where it is practically impossible to pass a ratifying resolution ${ }^{13}$ because all the shareholders are either the wrongdoing directors themselves or are connected with ${ }^{14}$ the wrongdoing directors. This factual matrix seems particularly likely in small or familyowned companies. The introduction of the disinterested shareholders' approval requirement in Hong Kong is thus by no means a straightforward matter.

Incidentally, it must also be noted that the proposed provision requiring disinterested shareholders' approval applies only to the ratification of breaches of directors' duties and not to the authorization in advance of prospective breaches of duty. The fact that section 239 of the UK Companies Act 2006 applies to ratification but does not extend to authorization has been criticized, as it appears odd that the legal position should be different depending on whether approval was given by the company on the day before or the day after the breach. ${ }^{15}$ In order to avoid such arbitrary inconsistencies, it is suggested that if the disinterested shareholders' approval requirement is adopted, that

10 Pursuant to s. 239 of the UK Companies Act 2006, any decision by a company to ratify conduct by a director amounting to negligence, default, breach of duty or breach of trust in relation to the company must be made by the members of the company, and without reliance on the votes in favour of the resolution by the director (if he or she is also a member of the company) or any member connected with him or her.

11 Above n. 9, para. 28.

12 See Koh, above n. 1.

13 J. Payne, 'A re-examination of ratification' (1999) 58(3) CLJ 604.

14 The detailed proposed rules in respect of what constitutes an entity connected with a director may be found in cl. 11(2) read with cl. 10.22(5d) of the draft Companies Bill in the First Phase Consultation of the draft Companies Bill (17 December 2009).

15 See Davies, above n. 1 at 583. 
it be extended in Hong Kong to also include the authorization in advance of prospective breaches of duty.

\section{ii. The Effect on the Statutory Derivative Action}

In the event that the disinterested shareholders' approval idea is eventually grafted into the Hong Kong law of ratification as a consequence of the recent company law reform efforts, the consequential question would then be what effect this should have on the statutory derivative action.

It is suggested that the addition of the disinterested shareholders' approval element would appear to sit strangely with the Hong Kong statutory derivative action in its current form. The effect of approval or ratification by members of a company on the bringing of a statutory derivative action in Hong Kong is markedly different from the position in the UK. In Hong Kong, the approval or ratification by the members of any conduct does not have the effect of preventing a member from bringing a statutory derivative action or requiring the court to refuse leave for the derivative action to be brought. ${ }^{16} \mathrm{How}-$ ever, the court may, after having regard to various matters in respect of the members who approved or ratified the relevant conduct, take into account the approval or ratification in deciding what judgment or order to make in respect of the derivative action. These factors include the extent of the members' independence of the conduct when they approved or ratified it, how well-informed about the conduct they were when deciding whether to approve or ratify it, and whether they were acting for proper purposes having regard to the interests of the specified corporation when they approved or ratified it. ${ }^{17}$

Therefore, the present position in Hong Kong is that ratification would not necessarily prevent a statutory derivative claim from being brought. The fact of ratification is merely one factor to be considered by the court in deciding whether to grant leave to commence the statutory derivative action. Given that at present (as earlier discussed), an errant director who is also a member generally may vote in his capacity as member in respect of the ratification of his own breach of duty as director, this must necessarily be the case. If the present position were that ratification was an automatic bar to the availability of the statutory derivative action, in a situation where the errant director controlled or was himself a majority shareholder, minority shareholders would then have no access to the statutory derivative action.

However, if the proposal involving confining ratification only to disinterested shareholders is indeed adopted in future, it is suggested that the statutory derivative action in Hong Kong should correspondingly be amended such that ratification by disinterested shareholders 
bars the possibility of a statutory derivative action. This would be in line with section 263(2)(c)(ii) of the UK Companies Act 2006, which provides that permission for the derivative action must be refused if the court is satisfied that the act in question has been ratified by the company since it occurred. If an act by a director has been ratified with disinterested shareholders' approval, the argument that a disgruntled minority shareholder should still be allowed to pursue a derivative action is much less strong. To allow derivative actions in such circumstances would arguably be to expose the company excessively to frivolous claims.

Incidentally, pursuant to section 263(3)(c) of the UK Companies Act 2006, in considering whether to give permission to continue the derivative action, the court must take into account whether an act that had not yet occurred could and would be likely to be authorized by the company before it occurred, or ratified by the company after it occurred. ${ }^{18}$ It is suggested that this provision should similarly be adopted in Hong Kong, as it would appear to be a pertinent factor in deciding whether the statutory derivative action should be granted.

As a side point, an interesting observation may be made in relation to the meaning of the term 'ratification'. The traditional understanding of ratification is that it puts directors in a position where they are treated as not having breached their duty to the company. It should thus follow, from a purely conceptual perspective, that once ratification has been effected, a company (either 'voluntarily' or via a derivative action) should not be entitled to sue the director. However, this is not the position under the current statutory derivative action framework in Hong Kong, where (as earlier discussed) ratification does not bar a statutory derivative action but is merely one of the factors to be considered by the court in deciding whether to grant leave for the derivative action to be brought. Thus under Hong Kong law at present, a company (via statutory derivative action) can still sue a director despite the fact that their breach was ratified. This highlights the nuanced, complex and somewhat confusing meaning of the term 'ratification'. Given that the term can be misleading and is subject to much historical baggage, it may be useful for subsequent statutory formulations to avoid the use of the term altogether, and instead spell out in plain and less ambiguous language what kind of resolution would bar a statutory derivative action or would have impact on the availability of the statutory derivative action. Indeed, it may be observed that a similar approach has been taken in the context of the fiduciary obligations of directors. The general duties of directors are listed in Chapter 2 of Part 10 of the UK Companies Act 2006, rather than relying on the

18 Similarly under s. 263(3)(d) of the UK Companies Act 2006, the court must take into account whether an act that has occurred could and would be likely to be ratified by the company. 
nebulous concept of 'fiduciary'. ${ }^{19}$ As Sir Peter Millett once observed, we 'should direct our efforts, not to finding a definition of the concept of "fiduciary", but to defining the characteristics of the various fiduciary relationships'. ${ }^{20}$ This appears to have been the approach in relation to the general duties of directors under the UK Companies Act 2006. It is suggested that a similar approach may be taken in the relation to the law on ratification of breaches of directors' duties.

\section{iii. Matters to be Considered in Examining Ratification}

In Hong Kong at present, the court may take into account the ratification by members in deciding whether to grant leave to commence the derivative action, after having regard to three matters in respect of the members who approved or ratified the relevant conduct. These three factors are the extent of the members' independence of the conduct when they approved or ratified it, how well-informed about the conduct they were when deciding whether to approve or ratify it, and whether they were acting for proper purposes having regard to the interests of the corporation when they approved or ratified it. ${ }^{21}$ The first of these three factors (namely the independence of the members) would be addressed by the proposed disinterested shareholders' approval requirement. The remaining two factors, however, merit closer attention.

In relation to the issue of how well-informed about the relevant conduct the shareholders were when deciding the question of ratification, it is suggested that this should prompt legislative stipulation that the directors whose conduct is being considered are required to provide full information to shareholders, in order for there to be effective ratification.

The third factor (namely, whether shareholders were acting for proper purposes having regard to the interests of the corporation) is much more complex. At present in Hong Kong, this is merely a factor to be considered by the court in deciding whether to allow the derivative action. The question is whether the bar should be raised higher, such that the fact that the shareholders were not acting for proper purposes having regard to the interests of the company renders the ratification ineffective. This has a flavour of imposing a limited fiduciary duty on shareholders towards the company. It has been suggested that the shareholders' decision as a whole should be examined to determine whether the ratification is in the company's best interests. ${ }^{22}$

However, there are serious complications in adopting a rule that ratification is ineffective if the voting shareholders viewed as a whole

19 Although this concept is still used in the context of the civil consequences of breach of the general duties under s. 178 of the UK Companies Act 2006.

20 P. Millett, 'Equity's place in the law of commerce' (1998) 114 (Apr) LQR 214.

21 Section $168 \mathrm{BF}(2)$ of the Companies Ordinance.

22 Above n. 13. 
did not act for proper purposes in the interests of the company. First, there is uncertainty as to which entity would constitute the company under such circumstances. In the context of directors' duties in Hong Kong, it has been observed that the position is that directors must act in good faith in the best interests of the company, meaning that a director owes a duty to act in the interests of all its shareholders, present and future ${ }^{23}$ (i.e. the shareholder primacy principle). While the shareholder primacy principle is logically coherent in the context of regulating the conduct of directors, the application of this principle seems somewhat circular and unhelpful if what is being regulated is the voting conduct of shareholders themselves.

Another alternative would be to adopt the enlightened shareholder value approach as enshrined in section 172 of the UK Companies Act 2006. However, the recent Hong Kong law reform Consultation Conclusions ${ }^{24}$ indicate that the notion of enlightened shareholder value had received only limited support in Hong Kong, and it thus appears unlikely that such an approach would be adopted in Hong Kong.

In addition, given that the general rule is that members are entitled to vote even if they have a personal interest in the subject matter that is different from the interests of the company, ${ }^{25}$ it is hard to see on principle why there should be a departure from this general rule where the question is one of ratification of a breach of directors' duty. For these reasons it is suggested that the failure by shareholders to vote in the best interests of the company should not determine the question of whether there has been effective ratification in Hong Kong.

\section{Authorization by Non-interested Directors}

In discussing the issue of ratification, a related question is whether non-interested directors should be empowered to authorize directors' breaches of the duty to avoid conflicts of interest, as provided for in section 175 of the UK Companies Act 2006. The obvious fear in this regard is that directors may be less than vigilant in authorizing each others' breaches of duty.

Nonetheless, it is suggested that the authorization by the board for breaches of directors' duty to avoid conflicts of interest should be introduced in Hong Kong. The fear of directors indiscriminately authorizing breaches must be balanced by the fact that such authorizations would be governed by directors' fiduciary duties. In addition, allowing directors the power to authorize breaches of duty in certain

23 Principle 1 of the Guide on Directors' Duties issued by the Companies Registry.

24 Consultation Conclusions on the Rewrite of the Companies Ordinance (relating to Company Names, Directors' Duties, Corporate Directorships and Registration of Charges) dated 10 December 2008, para. 20.

25 Above n. 8. 
instances is arguably more consistent with the modern view ${ }^{26}$ that the general meeting and the board are both organs of the company each deriving authority to exercise corporate powers from the articles, rather than the more traditional perspective that the board is somehow subject to the superior control of the general meeting. ${ }^{27}$ Moreover, executive directors who are concerned with the running of the company would arguably often be in a better position than minority shareholders to consider whether a particular act by a director ought to be authorized. (In contrast, however, it has been argued that the question of whether to forgive a director is not one within the ordinary business of the company, ${ }^{28}$ and thus not one that would necessarily be best decided by directors.)

If provisions for the authorization of breaches of directors' duty to avoid conflicts of interests are indeed introduced in Hong Kong, it is suggested that such board authorization should bar a minority shareholder from bringing a statutory derivative action. The issue of authorization for breaches of directors' duty is inextricably tied to the right to bring a statutory derivative action. To provide that breaches of the duty to avoid conflicts of interest can be authorized by the board but yet that derivative actions may be brought despite such authorization would seem to strip the authorization of much of its significance, as well as being conceptually incoherent. ${ }^{29}$

\section{Non-ratifiable Breaches}

The common law principles relating to the scope of non-ratifiable breaches has been the subject of much academic debate.$^{30}$ In particular, there has been much discussion as to how to reconcile the apparently conflicting cases of Cook v Deeks ${ }^{31}$ and Regal (Hastings) Ltd $\mathrm{v}$ Gulliver. ${ }^{32}$ The principle of non-ratifiable breaches is commonly formulated as stating that the majority of shareholders may not pass a resolution in order to expropriate to themselves company property, and thus a resolution to ratify a director's breaches of duty which would contravene this principle generally would not be effective. ${ }^{33}$ The underlying basis for the principle of non-ratifiable breaches appears to be the protection of minority shareholders as well as creditors.

26 As reflected in John Shaw \& Sons (Salford) Ltd v Shaw [1935] 2 KB 113.

27 Foss v Harbottle [1843] 2 Hare 461.

28 See Koh, above n. 1.

29 It must also be noted that s. 175(4b) of the UK Companies Act 2006 provides that the duty to avoid conflicts of interest is not infringed if the matter has been authorized by the directors.

30 See Koh, above n. 1 and Davies, above n. 1 at 586.

31 Cook v Deeks [1916] 1 AC 554.

32 Above n. 2.

33 See Davies, above n. 1 at 586. 
However, if the disinterested shareholders' approval element is introduced to the law of ratification in Hong Kong, this would effectively give disinterested minority shareholders a greater voice, and consequently the rationale behind the principle of non-ratifiable breaches would be substantially weakened. In the light of this, there appears to be much less reason to require the courts to scrutinize the nature of the transaction to see if it falls within the hazy ambit of the principle of non-ratifiable breaches.

In respect of protecting the interests of creditors, it is suggested that there are far more direct ways of protecting their interests (such as relying on the principles of unfair preference), rather than trying indirectly to protect the interests of creditors using the nebulous concept of non-ratifiable breaches. Given the extensive and continued uncertainty as to the scope of the principle of non-ratifiable breaches, it is thus suggested that the principle be abolished by statute.

As discussed above, ratification is already a factor to be considered in deciding whether leave should be granted for a statutory derivative action in Hong Kong. If the suggestion in this paper that ratification by disinterested shareholders should bar the statutory derivative action is adopted, then the need to clarify the concept of ratification and particularly to rid it of the problematic concept of non-ratifiable breaches is even stronger. One of the criticisms of the UK derivative action is that the retention of the concept of ratification (as one of the bars to the derivative action) results in the question of whether there has been an effective ratification dominating the application for leave. ${ }^{34}$ In order to avoid similar problems in Hong Kong it is thus important that the concept of ratification be properly clarified, and a simple and effective first step in this regard would be to abolish the notion of non-ratifiable breaches. The need for certainty and predictability in relation to the question of what constitutes effective ratification cannot be overstated.

\section{General Observations in Respect of the Codification of Common Law Principles}

This examination of the recent law reform efforts in Hong Kong relating to ratification is a useful springboard to wider observation about the effects of codification of common law principles and the divergence in company law regulation between England and Hong Kong.

Where the law on a particular issue is governed by case law principles rather than by statute in both England and Hong Kong, Hong Kong benefits from a wide pool of English cases, which serves as a useful supplement to the body of case law in Hong Kong. In turn, the

34 A. Reisberg, 'Derivative Claims under the Companies Act 2006: Much Ado About Nothing?' in J. Armour and J. Payne (eds), Rationality in Company Law: Essays in Honour of D.D. Prentice (Hart Publishing: Oxford, 2009). 
scope of influence of English law is effectively widened beyond its formal borders. For example, this mutually beneficial phenomenon may be historically observed in the context of the common law derivative action.

What then is the effect of legislative law reform which often takes the form of at least partial codification? Codification has been said to increase the exportability of law, as a code is more accessible than volumes of case law. ${ }^{35}$ Moreover, one of the merits of transplanting a branch of a country's laws is that the transplantation carries with it influence, and expands the scope of the country's laws beyond its boundaries. ${ }^{36}$ On a more pragmatic note, the lawyers of the 'exporting country' will benefit from the legal advice that will often be sought from them in relation to the transplanted provisions. ${ }^{37} \mathrm{~A}$ shared common legal framework also promotes mutual understanding which is conducive for business. If the partial codification of the law of ratification of breaches of directors' duties (as contained in section 239 of the UK Companies Act 2006) is eventually adopted in Hong Kong, this would then serve as another example of the transplantation of legislative provisions.

Nonetheless, the increased use of legislation as a means of legal development does in fact have disadvantages in terms of exportability and influence, which are particularly pronounced when other countries choose not to adopt the new legislative provisions. For instance, the statutory derivative action in Hong Kong differs from the English model in various significant ways. ${ }^{38}$ The implication of this for Hong Kong is that, where the statutory provisions in Hong Kong differ from the UK, the pool of English cases that are directly relevant for Hong Kong would be correspondingly diminished. This in turn has the effect of diminishing the scope of influence of English case law (and consequently English legal literature) in Hong Kong. It is thus clear that legislative law reform and codification does not always lead to increased exportability and influence.

Incidentally, another area in which this may be clearly observed is in the context of directors' duties. In Hong Kong, it was recently considered premature to codify comprehensively the fiduciary duties of directors ${ }^{39}$ and consequently most of the codified directors' duties in Chapter 2 of Part 10 of the UK Companies Act 2006 will not be adopted in Hong Kong. The limited exception to this is that the duty of care, skill and diligence is proposed to be statutorily formulated along

35 R. Goode, 'Removing the Obstacles to Commercial Law Reform' (2007) 123 (Oct) LQR 602.

36 Ibid.

37 Ibid.

38 The development of the statutory derivative action in Hong Kong is discussed in detail in P. Von Nessen, S.H. Goo and C.K. Low, The Statutory Derivative Action: Now Showing Near You' (2008) 7 JBL 627.

39 Above n. 24 at para. 20. 
the lines of section 174 of the UK Companies Act 2006. ${ }^{40}$ Moreover, various provisions in the UK Companies Act 2006 depart from the common law position, such as the new enlightened shareholder value approach in section 172 of the UK Companies Act 2006 which (as earlier discussed) received limited support and is thus most unlikely to be adopted in Hong Kong. ${ }^{41}$ In the light of this, English cases that interpret the codified directors' duties in the UK Companies Act 2006 are generally likely to be less persuasive in Hong Kong, given that Hong Kong would not have a similar legislative framework for directors' fiduciary duties.

This is thus another instance of how codification may have the effect of reducing influence. While greater reliance on legislation and codification of common law principles may at times result in greater exportability in the sense that a country's laws are more accessible to other countries, it may also result in a lessening of influence if other common law countries choose not to adopt the relevant statutory provisions.

\section{Conclusion}

This paper has considered the recent law reform proposals in Hong Kong in relation to the ratification of breaches of directors' duties, and also suggested several further reforms. This discussion has also provided a platform from which to consider some of the consequences of codification of common law principles and the divergence in company law principles between two common law jurisdictions, namely England and Hong Kong. It is hoped that the suggestions in this paper will promote greater coherence and clarity in the law relating to the ratification of breaches of directors' duties.

40 Above n. 24 at para. 24.

41 This is discussed in J.L. Yap, 'Considering the Enlightened Shareholder Value Principle' (2010) 31(2) The Company Lawyer 35. 